\title{
LEGISLATIVE MEASURES ADOPTED AT THE INTERNATIONAL LEVEL AGAINST FAKE NEWS
}

\author{
Maria-Lucia RUSU, Ramona-Elena HERMAN
}

\author{
"Nicolae Bălcescu" Land Forces Academy, Sibiu, Romania \\ rusu.maria@armyacademy.ro, herman.ramona@armyacademy.ro
}

\begin{abstract}
Social media has become an informational decision-making vector due to the rapid transfer and permanent consumption of messages by the population. In this virtual environment, information changes its qualitative and quantitative form, from real, manipulated to a fabricated form. As information grows, it travels more rapidly, responding to the needs and expectations of individuals, and at the same time there are the dangers of its distortion and intoxication, affecting the perception of the receptors. Fake news is a phenomenon created by social media, in which the communication scheme is vicious, it occurs due to the lack of information of the users. Fake news produces confusion and distraction, leading to fragmented public opinion. At international level, the act of combating this phenomenon was implemented by the authorities on a legislative basis, adopting anti-fake news laws with drastic sanctions, which differ according to the form of government in each state. The first country in the world to introduce an anti-fake news law is Malaysia. And the first European democratic state to initiate two bills against false information is France.
\end{abstract}

\section{Keywords: fake news, disinformation, social media, legislative measures, free speech.}

\section{Introduction}

The social news takes the forefront of opinion makers who capture and manipulate public attention through the use of modern technology. The capacity of an opinion maker is directly related to the degree of innovation in the use of the means offered by the current society. They choose the fastest, most widespread and affordable way to reach the population's dashed expectations. The main way is to use social media platforms and webpages to provide the instant spread and amplification of computer content.

One of the current problems is the manipulation and disinformation of the population through the fake news phenomenon. This phenomenon of fake news is a type of propaganda that delivers false, distorted or bizarre information through traditional media and social media. The purpose of the phenomenon is misleading, creating a social imbalance by lowering public confidence in state institutions. It creates confusion, distraction and social disturbances that can influence the public policy and foreign policies of a state, causing social fragmentation. Through this phenomenon the communication scheme is violated because the information provided by the source is not real, accurate, but it is just a false or manipulated and out of context piece of information, and when the receiver gets the message, he/she is not informed, but totally 
misinformed. Fake news relies on novelty and excitement to attract attention.

The phenomenon becomes credible as the message is better textured and accompanied by images and text and distributed by friends or trusted people.

The success of the phenomenon results from the vulnerability and convenience of the users of these digital platforms. And it does not depend on their age, but on the permanent online presence. Due to the alert life and the limited time for social interaction, the individual uses technology to communicate in digital environments, in the desire to be part of a community, or to belong to a group, which is called ,homodigitalis" [1].

The European Union, when referring to the phenomenon, uses the notion of "disinformation" because it involves more features "we define it as false, inaccurate, or misleading information designed, presented and promoted to intentionally cause public harm or for profit. The risk of harm includes threats to democratic political processes and values, which can specifically target a variety of sectors, such as health, science, education, finance and more" [2].

The term fake news does not include such a complex problem of misinformation, message information is not completely false, the truth is truncated, it is delivered through digital manipulation strategies, "includes some forms of automated accounts used for astroturfing, networks of fake followers, fabricated or manipulated videos, targeted advertising, organized trolling, visual memes" [3].

Disinformation promotes denigration and discourse that incites hatred and violence. The causes of the phenomenon are multiple, but the main ones are: social media, digitalisation of life, the political environment concerned with the provision of improbable information, the lack of professionalism in the media and the lack of education of the news consumers. And the effect of these causes flows over each individual, the right of every citizen to be informed, the attainment of human rights, the influence or impact on the electoral process, the undermining of media trust and the incitement to hatred, discrimination and violence.

\section{The strategy of fake-news phenomenon}

Search Engines (Google, Mozilla, Firefox, etc.) and social media (Facebook, Youtube, Twitter, Instagram) are great contentgenerating sites. But all of these are the main vehicles for spreading disinformation, and it is obviously possible to slightly target each individual, each profile according to problems, fears, to disinform or persuade $\mathrm{him} / \mathrm{her}$ in a particular direction of manipulation. Keep in mind that all these digital platforms are based on private companies that want to make profit; they do not force anyone to create an account on these platforms. There are many techniques used in this respect, and the European Union raises a flag about them. Video technology falsification techniques allow technology to mislead; for example, the University of Washington produced a synthetic Obama who can talk and give information, although it is not the real Barack Obama. Adobe Systems has also created a "VoCo" audio system, where a few to 20 minutes of a discourse are taken (an audio recording of a political character) and by using just those minutes they can produce everything, build any kind of speech that will send the information they want to be sent. In this sense, the European Union is even heading towards those who create these technologies.

People are informed only by reading the news headlines and have no patience or cognitive exercise to browse and analyze the text. On social networks, users are scrolling the pages in this way, working with artificial intelligence to attract and persuade the user to access the news (tab).

It is the dangerous actors that create a danger, which roll the information and jeopardize the construction of the European 
Union, are those who will destabilize the region, who will focus on nationalisms and autarkies.

Inside a fake news we will find manipulated and out-of-context information, or just an outlook that will mislead us or distort true information. Users can only come up with an opinion after checking the information in various sources. It can counterbalance this misinformation of an evil actor by checking the information before making it viral, if there is another source, another point of view in this regard. We should not directly trust the first piece of information we receive, meaning to click by (not to click on the bait information). The one who wants to make sensationalism viral aims at rating, clicks and great traffic on their site. It provides dubious, copy paste information.

\section{The comparative relationship between France and Malaysia}

In this context, solutions are sought at European and international level to combat and stop the fake news phenomenon by addressing strategies and adopting laws.

The first state to introduce a series of antifake news legislative measures is Malaysia. The law provides for a penalty of up to approximately EUR 110,000 and/or imprisonment for up to six years for creating, offering, publishing, printing, distributing, circulating, or disseminating fake news, and financially supporting these actions. This legislative measure also produces effects outside the Malaysian sovereign state:

"3. (1) If any offence under this Act is committed by any person, whatever his nationality or citizenship, in any place outside Malaysia, he may be dealt with in respect of such offence as if the offence was committed at any place within Malaysia. (2) For the purposes of subsection (1), this Act shall apply if, for the offence in question, the fake news concerns Malaysia or the person affected by the commission of the offence is a Malaysian citizen" [4]. "The Malaysian Communications and
Multimedia Commission (MCMC) has set up a website (Sebenarnya or "actually" in Malay) to counter fake news. The website caters to Malay-speaking audience and aims to debunk inaccurate news that appear on social media" [5].

France is the first European country to take action in combating this phenomenon. The French Parliament adopted two controversial law proposals, which voted against the broadcasting and manipulation of fake information during electoral periods, through the vote of the Assembly of Deputies. Initially, the two proposed laws met with rejections in the Senate, but eventually succeeded in gaining the majority vote and were approved. Under the provisions adopted, a party or candidate will be able to ask a judge to ask for the fake news broadcast before a national poll to be stopped. Digital platforms (Facebook, Twitter) are subject to transparency when broadcasting paid computer content. Restrictions are also imposed on televisions coordinated or influenced by foreign states that transmit distorted information in order to alter the polls. And those who do not comply will have their services suspended by the Superior Council of Audiovisual. There have been political parties that said these laws pose a risk to freedom of expression, and journalists' associations and syndicates have expressed concern about possible censorship. Publishers are required to publish the sources of funding behind some of the information they promote. Penalizing those who violate the law consists of fines of up to 75,000 euros.

\subsection{Similarities}

The connection between the two states consists in ensuring the right to free expression according to art. 10 of the Constitution of Malaysia, art. 10 and art. 11 of the Declaration of Human Rights and Citizen of 1789 of the French State. This right may be imposed on it if it conflicts with the Organic Law of the sovereign state in matters of security, international relations, defamation and instigation. Both 
legislative measures are aimed at preventing the financing of the fake news phenomenon with the intention of clarifying the source of misinformation.

\subsection{Differences}

First of all, anti-fake news legislative measures in Malaysia are more elaborate than in France because they impose more restrictions on the financing, support, promotion and dissemination of false information, for example art. 5 "Any person who directly or indirectly, provides or makes available financial assistance intending that the assistance be used, or knowing or having reasonable grounds to believe that the assistance will be used, in whole or in part, for the purposes of committing or facilitating the commission of an offence under section 4, commits an offence and shall, on conviction, be liable to a fine not exceeding five hundred thousand ringgit or to imprisonment for a term not exceeding ten years or to both" [6].

Secondly, the removal of false information falls under the responsibility of the person in possession, custody or contract, according to Art. 6, paragraph. (1) "It shall be the duty of any person having within his possession, custody or control any publication containing fake news to immediately remove such publication after knowing or having reasonable grounds to believe that such publication contains fake news. (2) Any person who fails to carry out the duty under subsection (1) commits an offence and shall, on conviction, be liable to a fine not exceeding one hundred thousand ringgit, and in the case of a continuing offence, to a further fine not exceeding three thousand ringgit for every day during which the offence continues after conviction" [7].

The anti-fake news law in Malaysia offers ways to combat the phenomenon through court orders for removal of false information accompanied by documents that prove their non-trustworthiness, such as the police report.

Thirdly, France, as opposed to Malaysia, does not offer complete legislative measures to curb the fake news phenomenon, the law Loi relative a la lutte contre les fausses informations [8] governs false information on the electoral periods of political elections. Since there is no clear definition of false news, according to French law, it remains unclear how magistrates will be able to judge what is false or true in political matters.

Fourthly, the phenomenon falls under criminal law in both states and is considered a criminal offense punishable by a criminal fine in the case of France, and in the case of Malaysia the refusal to remove false information is punished by imprisonment for up to 6 years and a criminal contravention.

Looking back retrospectively, Malaysia had very restrictive regimes in history and retains this severity of authority. There are assumptions that claim free speech is constrained and would be a discreet way of controlling the mass media.

\section{Legislative framework in Romania}

In Romania the subject fake news is increasingly debated, but at present there is no legislative framework to combat this misinformation phenomenon. This is explained by reference to Art. 10 of the European Convention on Human Rights which states that "every person has the right to freedom of expression", while art. 30 of the Constitution of Romania [9] prohibits censorship of any kind, so the Romanian press supervision body, the National Audio-visual Council, operates according to the Broadcasting Law no. $504 / 2002$, Art. 3, par. (2) which states that "all providers of audio-visual media services are required to provide objective information to the public by presenting the facts and events correctly and to foster the free formation of opinions" [10].

Meanwhile, the media respects the Uniform Code of Ethics adopted by the Media Organizations Convention in October 2009, in which "the journalist will take reasonable steps to check the information before 
publishing it. False information or what the journalist has good reasons to believe is false will not be published" (art 6.1.).

Also, freedom of expression is correlated with the individual's right to information, provided in art. 31 of the Convention of Romania "the mass media, public and private, are obliged to ensure the correct information of the public opinion" and art. 10 of the European Convention on Human Rights, "freedom of expression includes freedom of opinion and the freedom to receive or communicate information or ideas without the interference of public authorities and without taking into account borders".

As regards the sanctioning of false information communication, it is found in the Criminal Code, according to art. 404 that "The communication or dissemination by any means of falsified news, data or information or falsified documents, knowing their fake character, if this threatens national security, shall be punished by imprisonment from one to five years" [11].

\section{Measures adopted by the European Union}

The phenomenon of fake news is not a novelty for the European Union, what has actually changed is the speed and intensity with which social information is transmitted.

In autumn 2018, several associations signed a EU-wide Code of Practice on Disinformation [12] committing themselves to fighting misinformation. The European Council then warned that if voluntary measures are not enough, it will introduce mandatory rules on false news. The first reports recently presented to the European Executive by Google, Twitter, Facebook and Mozilla show that some progress has been made, particularly with regard to eliminating false accounts and limiting the visibility of websites that promote misinformation. However, the committee argues, additional measures are needed to ensure full transparency of political advertising until the start of the campaign for European Parliament elections in all EU Member States. At the same time, measures are needed to allow proper access to platform data for research purposes and to ensure adequate cooperation between platforms and each Member State through contact points in the rapid alert systems. The Community Executive is calling on Facebook to provide users with action and cooperation tools with those who check facts across the European Union, and asks Google to extend the tools for combating misinformation. The Commission also asked Twitter and Mozilla for more details on their plans to solve the issue of fake news.

The Code of Conduct obliges companies to signal political advertising, shut down false accounts, support users for informationbased decisions, and hinder the advertising revenue of accounts and websites that distort reality. According to news agencies, there are just third parties that could influence the electorate for Europarliamentary elections in order to promote populist and Eurosceptic political formations.

Internet giants have to work together to combat the fake news phenomenon, this is the requirement of the European Commission.

One of the measures comes from Facebook, which will show a clause warning that all political ads will be kept in a digital library that can be accessed by the public for a maximum of 7 years.

At EU level, a group of 39 experts (High Level Group on fake news and online disinformation) selected by the European Commission to combat false information and misinformation from the online environment was formed. Experts come from EU countries and specialize in intellectual property, copyright and media law. The group will advise the European Commission on the phenomenon of spreading false content, define the roles and 
responsibilities of relevant parties, assess the international dimension and the risks of this phenomenon, and make recommendations. Among the 39 experts there is also a representative of Romania, Professor Alina Bârgăoanu, Ph.D., Dean of the Faculty of Communication and Public Relations of the National School of Political and Administrative Studies, SNSPA - from Bucharest.

\section{Fighting the fake news phenomenon}

Since free speech is a pillar of democracy, it is a target of hybrid warfare and may be a weakness of these liberal regimes. It is intended to protect freedom of expression, but the problem arises when false information spreads and is being disseminated. Freedom of expression goes up to where the fundamental values of a state are affected.

Every person can be the victim of misinformation, online propaganda, and fake news. Permanent education is needed in relation to these risks, which obviously implies not only civic education in schools, but education in alternative media found in the Internet, free press, independent media and aware of all these hazards, can contribute to education of citizens. Hybrid threats include cybernetic components and use misinformation and propaganda to alter citizens' behaviours.

Another solution is to build deontological regulations for journalists to address the credibility of sources of information, real tools to dismantle false themes, and to impose increased transparency on media funding, promoting media literacy and collaborating with Internet and social media platforms.

Given the need to adapt to social realities, it is imperative to adopt legislative and strategic regulations to combat this phenomenon. But the measures imposed must be fed into the provisions of the European Convention on Human Rights without becoming a means of censorship. Misinformation is a vulnerability and its counteraction must be initiated by governments, not just by mass media and non-governmental organizations. The solution can be the strategic communication that promotes true and credible discourse. This is particularly important because misinformation is a multilateral manifestation and an evolving problem is not founded only on a single cause.

\section{Conclusions}

Throughout history, manipulation and persuasion have been used to achieve goals and gain power, but digital platforms have now become allies of these concepts in the struggle for supremacy. Fake news is the product of social media that aims to create confusion, confuse and fragment public opinion to unbalance a community or state. Internationally, the action to combat the fake news phenomenon has been implemented by the authorities on a legislative basis, adopting anti fake news laws with drastic sanctions, which differ according to the form of government in each state. If, in the case of a democratic state such as France, sanctions are more permissive and consist of financial penalties, the sanction is more drastic in the case of Malawi and can lead to up to six years in prison.

At European level, the Council of Europe is fighting against misinformation through measures and rules involving the giants of the Internet.

Locally, in Romania, there is no legislative framework to combat this phenomenon. The press operates according to the Broadcasting Law no. 504/2002 and the Code of Ethics and respect freedom of expression. Their contravention and sanction can only be found in the criminal code if false information endangers national security.

The law making of the fake news phenomenon must be treated with caution because it is a broad-spectrum topic that can lead to a restriction of the right to free speech. 


\section{References}

[1] Bârgăoanu Alina, \#FAKENEWS. Noua cursă a înarmării, București, Evrika, 2018 .

[2] European Commission, A multi-dimensional approach to disinformation, Report of the independent High level Group on fake news and online disinformation, Luxembourg, Publications Office of the European Union, 2018, p. 10.

[3] Idem.

[4] Parliament of Malaysia, Anti-Fake News Bill, Malaysia, 2018, p. 4, available at: http://www.cljlaw.com/files/bills/pdf/2018/MY_FS_BIL_2018_06.pdf accessed on 04 February 2019.

[5] Gulizar Haciyakupoglu, Jennifer Yang Hui, V. S. Suguna, Dymples Leong, and Muhammad Faizal Bin Abdul Rahman, Countering fake news a survey of recent global initiatives, S. Rajaratnam School of International Studies, Singapore, 2018, p.19.

[6] Parliament of Malaysia, Anti-Fake News Bill, Malaysia, 2018, p. 6.

[7] Idem.

[8] Loi relative a la lutte contre les fausses informations available at: https://cdn2.nextinpact.com/medias/fake-news---03-2017.pdf accessed on 04 February 2019.

[9] Guvernul României, Constituția României nr. 429/2003, Monitorul Oficial al României, Partea I, 2003, available on: https://www.ucv.ro/pdf/site/constitutia_romaniei.pdf accessed on 04 February 2019.

[10] Guvernul României, Legea audiovizualului, nr. 504/ 2002, art. 3, alin. (2), Monitorul Oficial al României, Partea I, București.

[11] Guvernul României, Noul Cod Penal actualizat -Legea 286/2009, Monitorul Oficial al României, București, 2019.

[12] European Council, EU-wide Code of Practice on Disinformation, Bruxelles, 2018. 